\title{
Infant mortality in the Matanza-Riachuelo River Basin. Comparison with the Autonomous City of Buenos Aires, the province of Buenos Aires, and Argentina (2010-2017)
}

\author{
Juliana Z. Finkelstein, M.D.a,b,c, María O. Codebó Ramalho Luz, M.D. ${ }^{a}$, \\ Lidia E. Feiock, B.S. ${ }^{a}$, Giselle Della Rosa, B.S. ${ }^{a, b}$ and Susana García, M.D ${ }^{a, c}$
}

\begin{abstract}
Introduction. Infant mortality rate (IMR) is an indicator of health and socioeconomic, environmental, and health care conditions. Open dumps and sewage and industrial waste make the Matanza-Riachuelo River Basin the most polluted in Argentina.

Objective. To analyze infant mortality (IM) in the Matanza-Riachuelo River Basin compared to Argentina, the province of Buenos Aires (PBA), and the Autonomous City of Buenos Aires (CABA), and its evolution between 2010 and 2017. Population and methods. Descriptivestudy based on data from Argentina's Ministry of Health.

Results. In 2017, the IMR was $9.4 \%$ in the Matanza-Riachuelo River Basin; $9.3 \%$ in Argentina; $9.4 \%$ in PBA; and $6.9 \%$ in CABA. Between 2010 and 2017, the IMR in the MatanzaRiachuelo River Basin decreased by $20.6 \%$, similar to PBA and Argentina. No reduction was observed in CABA.

In the 4 jurisdictions, perinatal conditions were the leading cause of death, followed by congenital malformations and respiratory diseases. For respiratory diseases only, the risk in the MatanzaRiachuelo River Basin was 4 times higher than in CABA (relative risk: 3.9; $95 \%$ confidence interval: 1.4-10.7).

Conclusion. The structure of causes, evolution, and risk of IM in the Matanza-Riachuelo River Basin, Argentina, and PBA was similar between 2010 and 2017. IMR was lower in CABA than in the Matanza-Riachuelo River Basin, but no reduction was observed in the former. The risk of IM was higher in the Matanza-Riachuelo River Basin than in CABA, at the expense of the increased risk of respiratory disease.

Key words: infant mortality, environmental pollution, public health.
\end{abstract}

http: / / dx.doi.org/10.5546/ aap.2020.eng.313

Juliana Z. Finkelstein, M.D.:

julianazoefinkelstein@ hotmail.com

Funding:

None.

Conflict of interest:

None.

Received: 1-17-2020

Accepted: 4-6-2020

\section{INTRODUCTION}

Infant mortality rate (IMR) is an indicator of the health status of the general population and of infants younger than 1 year old in particular. It is also an indicator of socioeconomic and environmental conditions, as well as of conditions related to health care system accessibility and quality. ${ }^{1}$

In September 2015, the Member States of the United Nations approved the 2030 Agenda for Sustainable Development in order to end poverty, fight against inequality and injustice, and combat climate change. One of its goals recognizes the need to reduce mortality among children under 5 years of age. Worldwide, approximately $26 \%$ of mortality and more than $40 \%$ of total diseases among children under 5 years of age are attributed to environmental factors. ${ }^{3,4}$

In spite of global advances made in health care in the last decades, millions of children are still dying due to reducible causes. This evidences difficulties in the quality and accessibility of basic health services, nutritional status, access to safe water, and environmental sanitation. ${ }^{5-7}$

The Matanza-Riachuelo river flows for $64 \mathrm{~km}$ from the west of the province of Buenos Aires (PBA) to the Río de la Plata Estuary, and its basin encompasses $2200 \mathrm{~km}^{2}$ (Figure 1). The presence of open dumps, the dumping of sewage and industrial waste from more than 25000 industrial facilities and service activities pollute the surface water, groundwater, soil, and air of the Matanza-Riachuelo River Basin. ${ }^{8-10}$ 
This basin is one of the most polluted in Argentina, one of the 5 most polluted in Latin America, and one of the 30 most polluted in the world. ${ }^{11}$ With more than 4 million inhabitants, it is a densely populated area where pollution exposure coexists with poor housing conditions and important socioeconomic vulnerabilities. ${ }^{12}$

In September 2017, the Environmental Health and Education Division (Dirección de Salud y Educación Ambiental, DSyEA) of the MatanzaRiachuelo River Basin Authority (Autoridad de la Cuenca Matanza Riachuelo, ACUMAR), together with the Argentine Toxicological Association, the Argentine Society of Pediatrics, and the Argentine Society of Medicine, established a list of diseases related to environmental exposure in order to screen and control their presence in neighborhoods of the Matanza-Riachuelo River Basin. Some of the included events are prematurity and low birth weight, as well as congenital malformations and respiratory diseases. These causes account for more than $85 \%$ of infant mortality in Argentina. ${ }^{13}$

The objective of this study was to analyze the structure of infant mortality causes in the Matanza-Riachuelo River Basin, compared to Argentina, the PBA, and the Autonomous City of
Buenos Aires (CABA), and its evolution between 2010 and 2017.

\section{POPULATION AND METHODS}

A descriptive study on infant mortality (deaths among infants younger than one year old) in the Matanza-Riachuelo River Basin, compared to Argentina, the PBA and the CABA, was conducted based on the database of Vital Statistics of the Health Statistics and Information Department (Dirección de Estadística e Información en Salud, DEIS) from Argentina's Ministry of Health for the 2010-2017 period.

All births and deaths occurring in Argentina are recorded on a legally binding certificate and included in a statistical report. Live birth statistical reports (LBSRs) and death statistical reports (DSRs) are consolidated at a national and jurisdictional level. Every year, the DEIS of Argentina's Ministry of Health consolidates, analyzes and publishes the main results of Vital Statistics based on the corresponding statistical reports. ${ }^{14}$

This analysis included data on all live births and all deaths of infants younger than one year old occurred in the Matanza-Riachuelo River Basin, Argentina, the PBA, and the CABA, recorded by jurisdiction of maternal place of

FIGURE 1. Location of the Matanza-Riachuelo River Basin in the northwest region of the province of Buenos Aires and the south of the Autonomous City of Buenos Aires

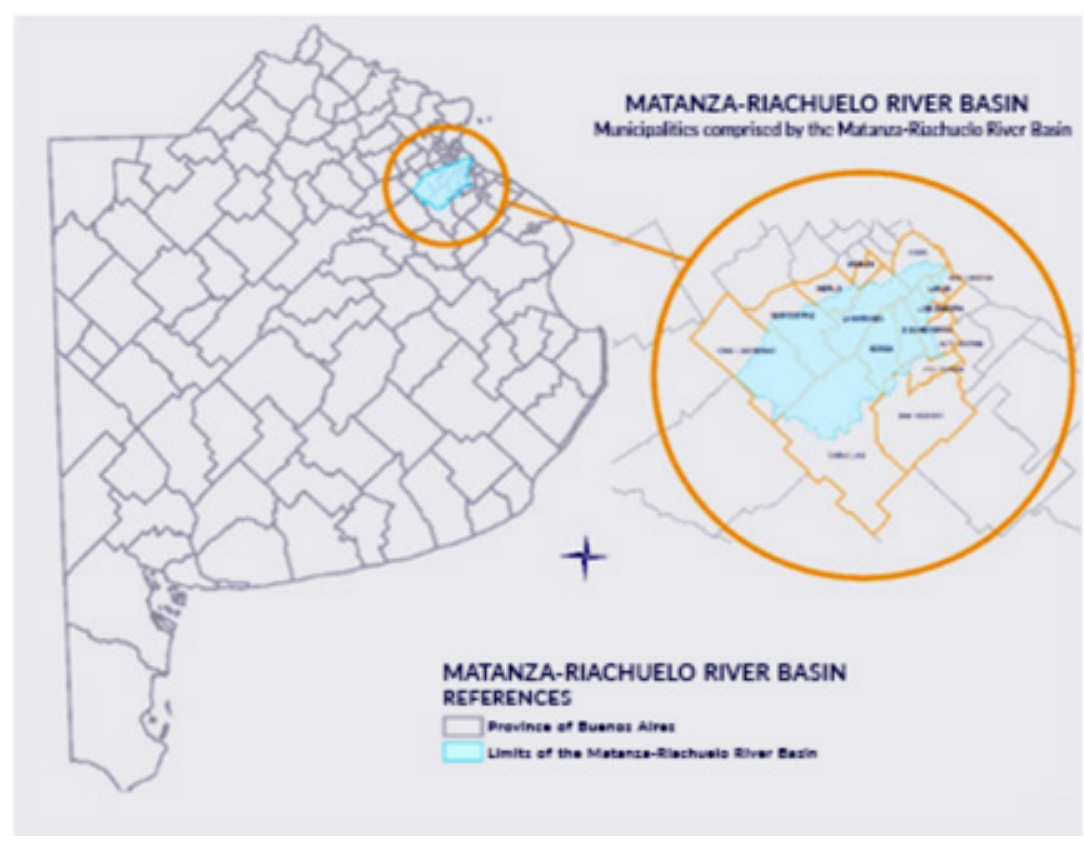

Source: Matanza-Riachuelo River Basin Authority (ACUMAR). 
residence. For the analysis of infant mortality and the structure of causes, instead of absolute numbers, rates were used to make comparisons with other populations and over time. IMR, cause-specific IMR, and proportional mortality by cause were estimated; all of them continuous quantitative variables. ${ }^{15}$

IMR related infant deaths occurred over one year to the number of recorded live births over that same year in the corresponding jurisdiction and was expressed per 1000 live births. ${ }^{16}$ Causespecific IMR included deaths from a specified cause among infants younger than one year of age in relation to the number of recorded live births over the same year in that jurisdiction and was expressed per 1000 live births. ${ }^{17}$ Proportional mortality by cause indicates the relation between infant deaths from a specified cause and total infant deaths, and is expressed as percentage.

The information from the Matanza-Riachuelo River Basin was estimated by integrating data from 14 municipalities from the PBA and the 4 communes of the CABA that compose it (highest level of disaggregation of the information from the DEIS). The 14 municipalities from the PBA comprised by the Matanza-Riachuelo River Basin are Almirante Brown, Avellaneda, Cañuelas, Esteban Echeverría, General Las Heras, La Matanza, Lanús, Lomas de Zamora, Marcos Paz, Merlo, Morón, Presidente Perón, and San Vicente. The Matanza-Riachuelo River Basin includes the following communes of CABA: 4, 7, 8, and 9.

The relative risk (RR) $(95 \%$ confidence interval [CI]) of death in the first year of life was estimated considering infant death as an event and maternal residence in the Matanza-Riachuelo River Basin as exposure, compared to the CABA, the PBA, and Argentina; and the risk of death by the main causes of infant death in the Matanza-Riachuelo River Basin was analyzed in relation to the same jurisdictions. Given that RR assesses the risk of an event (infant death) happening in an exposed group (maternal residence in the MatanzaRiachuelo River Basin) compared to the risk of the same event happening in an unexposed group (children of mothers who do not live in the Matanza-Riachuelo River Basin), when estimating this indicator in the comparison jurisdictions, deaths and live births of infants whose mothers lived in the communes or municipalities comprised by the Matanza-Riachuelo River Basin were excluded. ${ }^{18}$

The data processing software programs Microsoft Excel and Epidat 4.2 were used. This study was conducted based on secondary sources, without using personal data; therefore, no informed consent nor protocol approval by the Ethics Committee were required.

\section{RESULTS}

In 2017, the recorded IMR was $9.45 \%$ in the Matanza-Riachuelo River Basin; $9.33 \%$ in Argentina; and $9.4 \%$ in the PBA. No statistically significant differences were observed between the PBA and Argentina and the Matanza-Riachuelo River Basin (Table 1). In the CABA, the IMR was $6.92 \%$ and the risk of infant death was $40 \%$ lower than in the Matanza-Riachuelo River Basin (RR: 1.4; $95 \%$ CI: 1.2-1.6) (Tables 1 and 3).

The analysis of IMR evolution over the 20102017 period showed a decreasing evolution in the Matanza-Riachuelo River Basin (a 20.6\% reduction), in Argentina (a $21.5 \%$ reduction), and in the PBA (a $21.6 \%$ reduction). In the CABA, which was the district with the lowest IMR among those analyzed, fluctuations were

TABLE 1. Live births, deaths among infants younger than one year old, and infant mortality rate, by jurisdiction of maternal place of residence. Year 2017. Matanza-Riachuelo River Basin, Autonomous City of Buenos Aires, province of Buenos Aires, and Argentina

\begin{tabular}{lcccc}
\hline $\begin{array}{l}\text { Jurisdiction of maternal } \\
\text { place of residence }\end{array}$ & Live births & $\begin{array}{c}\text { Deaths among infants } \\
\text { younger than one year old }\end{array}$ & IMR (per 1000 LBs) & $\begin{array}{c}\text { 95\% CI, } \\
\text { IMR }\end{array}$ \\
\hline MRRB & 99715 & 942 & 9.45 & $8.85-10.07$ \\
Argentina & 704609 & 6579 & 9.33 & $9.11-9.34$ \\
PBA & 262721 & 2471 & 9.40 & $9.04-9.78$ \\
CABA & 35840 & 248 & 6.92 & $6.08-7.84$ \\
\hline
\end{tabular}

MRRB: Matanza-Riachuelo River Basin; CABA: Autonomous City of Buenos Aires; PBA: province of Buenos Aires; IMR: infant mortality rate; LBs: live births; CI: confidence interval.

Source: Developed based on data provided by the DEIS of the Ministry of Health of Argentina. Year 2017. MRRB, CABA, PBA, and Argentina. 
observed over this period: 2010 started and 2017 ended with similar values (7\%o and $6.9 \%$, respectively) (Figure 2).

The analysis of the relative weight of each group of causes of infant mortality in the Matanza-Riachuelo River Basin in 2017 showed that most recorded deaths $(49 \%)$ corresponded to conditions originating in the perinatal period (mainly low birth weight and prematurity). Congenital malformations were in second place $(28 \%)$. Respiratory diseases were the third cause $(6.8 \%)$; followed by deaths with an ill-defined underlying cause $(6 \%)$ and the remaining causes $(10.2 \%)$ (Table 2).

FIGURE 2. Evolution of infant mortality rate by jurisdiction of maternal place of residence. 2010-2017 period. Matanza-Riachuelo River Basin, Autonomous City of Buenos Aires, province of Buenos Aires, and Argentina

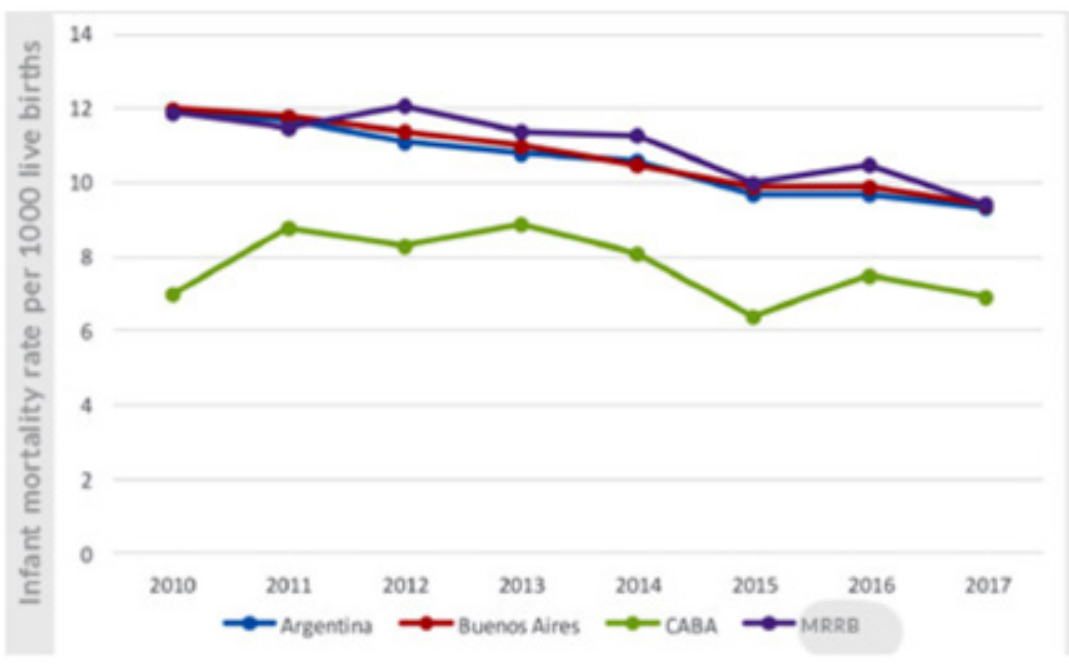

CABA: Autonomous City of Buenos Aires; MRRB: Matanza-Riachuelo River Basin.

Source: Developed based on data provided by the DEIS of the Ministry of Health of Argentina. 2010-2017 period.

MRRB, CABA, PBA, and Argentina.

TABLE 2. Infant mortality by cause and jurisdiction of maternal place of residence. Year 2017. Matanza-Riachuelo River Basin, Autonomous City of Buenos Aires, province of Buenos Aires, and Argentina

\begin{tabular}{lccccccc}
\hline & Total & $\begin{array}{c}\text { Perinatal } \\
\text { conditions }\end{array}$ & $\begin{array}{c}\text { Congenital } \\
\text { malformations }\end{array}$ & $\begin{array}{c}\text { Respiratory } \\
\text { diseases }\end{array}$ & $\begin{array}{c}\text { Ill-defined } \\
\text { Other } \\
\text { causes }\end{array}$ \\
\hline MRRB & Infant deaths & 942 & 462 & 264 & 64 & 56 & 96 \\
& IMR (per 1000 LBs) & 9.45 & 4.63 & 2.64 & 0.64 & 0.56 & 0.96 \\
& $95 \%$ CI, IMR & $8.85-10.07$ & $4.22-5.07$ & $2.34-2.98$ & $0.49-0.82$ & $0.42-0.73$ & $0.78-1.18$ \\
& Proportional mortality & $100 \%$ & $49 \%$ & $28 \%$ & $6.80 \%$ & $6.00 \%$ & $10.20 \%$ \\
Argentina & Infant deaths & 6579 & 3383 & 1864 & 402 & 294 & 636 \\
& IMR (per 1000 LBs) & 9.33 & 4.8 & 2.64 & 0.57 & 0.42 & 0.9 \\
& 95\% CI, IMR & $9.11-9.34$ & $4.64-4.81$ & $2.58-2.77$ & $0.52-0.63$ & $0.37-0.47$ & $0.83-0.98$ \\
& Proportional mortality & $100 \%$ & $51.40 \%$ & $28.30 \%$ & $6.10 \%$ & $4.50 \%$ & $9.70 \%$ \\
PBA & Infant deaths & 2471 & 1176 & 730 & 175 & 146 & 244 \\
& IMR (per 1000 LBs) & 9.4 & 4.47 & 2.78 & 0.67 & 0.55 & 0.93 \\
& 95 \% CI, IMR & $9.04-9.78$ & $4.22-4.74$ & $2.58-2.99$ & $0.57-0.77$ & $0.47-0.65$ & $0.82-1.05$ \\
& Proportional mortality & $100 \%$ & $47.60 \%$ & $29.50 \%$ & $7.10 \%$ & $5.90 \%$ & $9.90 \%$ \\
CABA & Infant deaths & 248 & 133 & 77 & 15 & 3 & 20 \\
& IMR (per 1000 LBs) & 6.92 & 3.71 & 2.14 & 0.42 & 0.08 & 0.55 \\
& 95 $\%$ CI, IMR & $6.08-7.84$ & $3.11-4.39$ & $1.69-2.68$ & $0.23-0.69$ & $0.02-0.25$ & $0.34-0.86$ \\
& Proportional mortality & $100 \%$ & $53.60 \%$ & $31.10 \%$ & $6 \%$ & $1.20 \%$ & $8.10 \%$ \\
\hline
\end{tabular}

MRRB: Matanza-Riachuelo River Basin; CABA: Autonomous City of Buenos Aires; PBA: province of Buenos Aires; IMR: infant mortality rate; LBs: live births; CI: confidence interval.

Source: Developed based on data provided by the DEIS of the Ministry of Health of Argentina. Year 2017. MRRB, CABA, PBA, and Argentina. 
The structure of causes of infant mortality was similar in the Matanza-Riachuelo River Basin, Argentina, the PBA, and the CABA. In the 4 jurisdictions, conditions originating in the perinatal period were the leading cause of death, followed by congenital malformations and respiratory diseases. In 2017, these 3 causes, related to environmental exposure, accounted for $83.8 \%$ of infant deaths in the Matanza-Riachuelo River Basin, $85.9 \%$ in Argentina, $84.2 \%$ in the PBA, and $90.7 \%$ in the CABA (Table 2).

The IMR due to perinatal conditions in the Matanza-Riachuelo River Basin $(4.6 \%$ ) was higher than in the CABA $(3.7 \%$ ) and the PBA $(4.5 \%$ ) , although it was lower than the total for the country $(4.8 \%$ o). Such differences were not statistically significant (Tables 2 and 3 ).

The second leading cause were congenital malformations, with a $2.6 \%$ rate in the MatanzaRiachuelo River Basin, the same as in Argentina, higher than in the CABA $(2.1 \%$ ), and lower than in the PBA $(2.8 \%$ ). Such differences were not statistically significant either (Tables 2 and 3 ).

Deaths caused by respiratory diseases showed a $0.6 \%$ specific IMR in the Matanza-Riachuelo River Basin, the same as in Argentina, higher than in the CABA $(0.4 \%$ ), and lower than in the PBA $(0.7 \%)$. When comparing the risk of infant death due to respiratory diseases, the risk in the Matanza-Riachuelo River Basin was similar to that of Argentina and the PBA, but 4 times higher than in the CABA (RR: 3.9; $95 \%$ CI: 1.4-10.7) (Tables 2 and 3 ).

\section{DISCUSSION}

The IMR reduction in the Matanza-Riachuelo River Basin in the analyzed period (2010-2017) was $20.6 \%$, similar to the PBA $(21.6 \%)$ and Argentina (21.5\%), and also to the reduction observed in Latin America and the Caribbean $(19.9 \%)$ and the world $(20.8 \%) \cdot{ }^{19}$ It is worth mentioning that, in the analyzed period, this reduction could not be observed in the CABA.

In 2017, 5.4 million of children younger than 5 years old died worldwide, and 4.1 million of those deaths occurred during the first year of life ( $76 \%$ of deaths among children younger than 5 years old). The main causes were prematurity, pneumonia, complications during delivery, congenital anomalies, diarrheal diseases, neonatal sepsis, and malaria, all closely related to the environment. .0-22 $^{20}$

Preterm birth is associated with diseases and disability for life. Prematurity, which accounted for $18 \%$ of infant deaths, has been associated with exposure to air pollution, household air pollution, tobacco smoke, chemical substances, and lack of adequate access to safe water, lack of sanitation and hygiene. ${ }^{7,22}$

Respiratory infections accounted for $16 \%$ of deaths. ${ }^{22}$ The World Health Organization (WHO) attributes more than $50 \%$ of lower respiratory infections in children under five years in lowand middle-income countries to household air pollution from the use of solid fuels for cooking and ambient air pollution. ${ }^{7}$

Nine percent of global infant deaths are due to congenital anomalies, related to tobacco smoke exposure, and exposure to pesticides, organic solvents, air pollution, etc. ${ }^{7}$ Diarrheal diseases cause about $8 \%$ of all deaths in children under five years, related to access to safe water, sanitation, and hygiene. ${ }^{22}$ Over 300000 deaths in children under five years are attributed to malaria, and concerns are expressed regarding dengue, which is the most rapidly spreading mosquito-borne viral disease in the world with half of the world's population being at risk. ${ }^{7}$

When comparing the results of this study

TABLE 3. Comparison of the risk of infant death between the Matanza-Riachuelo River Basin and Argentina, the province of Buenos Aires, and the Autonomous City of Buenos Aires, expressed as relative risk and $95 \%$ confidence interval

\begin{tabular}{lccccc}
\hline & & Total & Perinatal conditions & Congenital malformations & Respiratory diseases \\
\hline Argentina & RR & 1.01 & 0.95 & 1.14 & 1.14 \\
& $95 \%$ CI & $0.95-1.08$ & $0.86-1.05$ & $1.00-1.30$ & $0.87-1.50$ \\
PBA & RR & 1.02 & 1.07 & 0.94 & 0.91 \\
& $95 \%$ CI & $0.94-1.10$ & $0.96-1.20$ & $0.81-1.09$ & $0.67-1.24$ \\
CABA & RR & 1.4 & 1.22 & 1.21 & 3.9 \\
& $95 \%$ CI & $1.19-1.65$ & $0.98-1.53$ & $0.90-1.63$ & $1.4-10.7$ \\
\hline
\end{tabular}

CABA: Autonomous City of Buenos Aires; PBA: province of Buenos Aires; RR: relative risk; CI: confidence interval. Source: Developed based on data provided by the DEIS of the Ministry of Health of Argentina. Year 2017. MRRB, CABA, PBA, and Argentina. 
with the global situation, in the jurisdictions comprised by the Matanza-Riachuelo River Basin, respiratory diseases accounted for less than half the relative weight of that found globally; diarrheal diseases had a low relative weight; and dengue disease, together with malaria, were not identified as causes of infant death in Argentina, whereas perinatal conditions had a higher relative weight in the analyzed jurisdictions from the Matanza-Riachuelo River Basin than that observed worldwide., ${ }^{7,22}$ Regardless of the relative weight of each of these causes, perinatal conditions, congenital malformations, respiratory and infectious diseases, and their close relation to environmental exposure accounted for the leading causes of infant death in the MatanzaRiachuelo River Basin, the PBA, the CABA, Argentina, and the rest of the world., 722

Worldwide, the structure of causes of death in the first years of life is strongly determined by the structure of causes of infant deaths in Asia and Africa, which account for more than $80 \%$ of global deaths in the first years of life. ${ }^{5}$ In these continents, living conditions entail a greater vulnerability to environmental threats, which would explain the differences in the structure of causes of death in relation to what occurs in the Matanza-Riachuelo River Basin in particular and in Argentina in general.

Of the population in the Matanza-Riachuelo River Basin, $24.62 \%$ does not have access to the drinking water supply network $(16.1 \%$ in Argentina, $24.9 \%$ in the PBA, and $0.4 \%$ in the CABA), $52.4 \%$ does not have access to sewer systems (46.9\% in Argentina, $52.4 \%$ in the PBA, and $1.8 \%$ in the CABA), and $11.2 \%$ has unmet basic needs (12.5\% in Argentina, $11.2 \%$ in the PBA, and $7 \%$ in the CABA). ${ }^{23,24}$ In this regard, it would be interesting to analyze the impact of social determinants on results of environmental exposure; however, it was not possible in this study given that the corresponding statistical reports lacked these data.

For these reasons, not only in the MatanzaRiachuelo River Basin but also in Argentina, it is essential to reduce the risk of environmental exposure and improve preconception conditions among women of childbearing age, offer an early and adequate antenatal care, and provide care during labor in safe maternity centers with the corresponding level of care according to risk. In addition, it is necessary to improve living conditions and health checkups among young children.
This study has some weaknesses, such as having analyzed data published by the DEIS, obtained from the Vital Statistics System and based on LBSRs and DSRs, and the fact that event under-recording (birth or death) or an incorrect identification of the cause of death in DSRs may affect analysis results. Notwithstanding this, and taking into account the strengths of the study, it is worth noting that more than $99.5 \%$ of births in Argentina take place in health facilities and that a mandatory requirement for burial implies the concurrent recording of death certificates and DSRs, therefore reducing any potential underrecording of these events.

\section{CONCLUSION}

The risk of IM and its structure of causes were similar in the Matanza-Riachuelo River Basin, Argentina, and the PBA. The risk of IM in the Matanza-Riachuelo River Basin was higher than in the CABA. The risk of IM by cause only evidenced a higher risk of IM due to respiratory diseases in the Matanza-Riachuelo River Basin than in the CABA. The IMR reduction was similar between 2010 and 2017 in the Matanza-Riachuelo River Basin, the PBA, and Argentina. No IMR reduction was observed in the $\mathrm{CABA}$ during the analyzed period.

\section{REFERENCES}

1. Finkelstein J, Duhau M, Speranza A, Marconi E, et al. Evolución de la mortalidad infantil en Argentina en el marco de los Objetivos del Desarrollo del Milenio. Arch Argent Pediatr. 2016; 114(3):216-22.

2. Programa de las Naciones Unidas para el desarrollo. Objetivos de Desarrollo sostenible. 2015. [Accessed on: November $1^{\text {st }}$, 2019]. Available at: http: / / www.undp.org/ content/undp/es/home/sustainable-development-goals. html.

3. Organización Mundial de la Salud. ¿La Herencia de Un Mundo Sostenible? Atlas Sobre Salud Infantil y Medio Ambiente. Ginebra: OMS; 2018.

4. Quiroga D, Fernández R, Paris E (comp.).Salud Ambiental Infantil: Manual para Enseñanza de Grado en Escuelas de Medicina. Buenos Aires: Ministerio de Salud de la Nación, Organización Panamericana de la Salud; 2010.

5. UNICEF, WHO, World Bank Group and United Nations. Levels and Trends in Child Mortality: Report 2019, Estimates developed by the United Nations Inter-agency Group for Child Mortality Estimation. New York, 2019. [Accessed on: December $\left.1^{\text {st }}, 2019\right]$. Available at: https: / / www.unicef.org/ report s/ levels-and-t rends-child- mortality-report-2019.

6. Pronczuk-Garbino J (ed.). Children's Health and the Environment: A Global Perspective. Ginebra: OMS; 2005.

7. Organización Mundial de la Salud. ¡No contamines mi futuro! El Impacto de los factores medioambientales en la salud infantil. Ginebra: OMS; 2017.

8. Cuerpo Colegiado de ACUMAR. Informe especial de seguimiento Cuenca Matanza Riachuelo. 2003-2005. [Accessed on: November 1 $\left.{ }^{\text {st }}, 2019\right]$. Available at: http:// cdi.mecon.gov.ar/bases/docelec/az1260.pdf. 
9. Nápoli A, García Espil J. Recomposición ambiental de la Cuenca Matanza-Riachuelo. Una oportunidad Histórica que aún reclama un fuerte compromiso político y más eficiencia en la gestión. Informe Ambiental FARN. Buenos Aires:FARN;2011. [Accessed on: April $\left.6^{\text {th }}, 2020\right]$. Available at: http: / / farn.org.ar/wp-content/ uploads / 2013/02/ IAF2010napoli.pdf.

10. Nápoli A. Una política de Estado para el Riachuelo. Informe Ambiental FARN. Buenos Aires: FARN; 2009. [Accessed on: April $6^{\text {th }}$, 2020]. Available at: https: / / farn.org.ar/wpcontent/uploads / 2013/02/IAF2009napoli.pdf.

11. Blacksmith Institute. The world's worst polluted places. The top ten of the dirty thirty. Nueva York: Blacksmith Institute; 2007.

12. Marconi A. Mortalidad en la región de la Cuenca MatanzaRiachuelo Análisis período 2001-2009. Rev I-Salud. 2015; 10(48):49-60.

13. Sociedad Argentina de Pediatría, Sociedad Argentina de Medicina, Asociación Toxicológica Argentina D de S y EA (ACUMAR). Enfermedades relacionadas al medio ambiente en el ámbito de la Cuenca Matanza Riachuelo: Acta acuerdo de sociedades científicas. In: Estrategias de Salud Ambiental en la Cuenca Matanza Riachuelo. Buenos Aires: ACUMAR; 2018:110-5. [Accessed on: November $1^{\text {st }}$ 2019]. Available at: http://www.acumar.gob.ar/ wp-content/ uploads / 2016/12/IF-2018-53235166-APNDSYEAACUMAR-Documento-de-Salud-AP.pdf.

14. Dirección de Estadísticas e Información de Salud. Estadísticas Vitales Información Básica. 2017; Serie 5(61). Buenos Aires: DEIS; 2018. [Accessed on: April $6^{\text {th }}, 2020$ ]. Available at: http: / / www.deis.msal.gov.ar/wp-content / uploads/2019/01/Serie5Nro61.pdf.

15. Organización Panamericana de la Salud. Lineamientos básicos para el análisis de la mortalidad. Washington: OPS; 2012.

16. Dirección de Estadísticas e Información de Salud (DEIS). Definiciones y conceptos. [Accessed on: April $\left.6^{\text {th }}, 2020\right]$.
Available at: http:/ / www.deis.msal.gov.ar/index.php/ definiciones-y-conceptos/.

17. Dirección de Estadísticas e Información de Salud (DEIS). Presentación Anuario 2017. [Accessed on: April $6^{\text {th }}, 2020$ ]. Available at: http: / / www.deis.msal.gov.ar/wp-content/ uploads / 2019/01/Presentacion-anuario-2017-DEIS.pdf.

18. Ortíz Z, Esandi ME, Bartman M. Epidemiología Básica y Vigilancia de la Salud. $2^{\text {da }}$ ed. Buenos Aires: MINSAL, VIGI+A, World Bank; 2004.

19. The World Bank. Data. Mortality rate, infant (per 1,000 live births). [Accessed on: April $6^{\text {th }}$, 2020]. Available at: https: / / data.worldbank.org/indicator/SP.DYN.IMRT.IN.

20. Organización Mundial de la Salud. Reducción de la mortalidad en la niñez. Septiembre de 2019. [Accessed on: April $\left.6^{\text {th }}, 2020\right]$. Available at: https: / / www.who.int/ es/news-room / fact-sheets / detail / children-reducingmortality.

21. UNICEF. Mortalidad infantil: ¿quéhay detrás de los datos? [Accessed on: April $6^{\text {th }}, 2020$ ]. Available at: https: / / www. unicef.es / blog/mortalidad-infantil-que-hay-detras-de-losdatos.

22. United Nations Inter-agency Group for Child Mortality Estimation. Level \& Trends in Child Mortality. 2018. [Accessed on: April $6^{\text {th }}$, 2020]. Available at: https:/ / data. unicef.org/wp-content/uploads / 2018/09/UN-IGMEChild-Mortality-Report-2018.pdf

23. Instituto Nacional de Estadísticas y Censos. Necesidades básicasinsatisfechas. Censo Nacional de Población, Hogares y Viviendas 2010. Argentina, 2010. [Accessed on: November $1^{\text {st }}$, 2019]. Available at: https:// www.indec.gob.ar/indec/ web / Nivel4-Tema-4-47-156.

24. Dirección de Salud y Educación Ambiental, ACUMAR. Dosier Don Juan, La Matanza. CABA. 2019. [Accessed on: April $6^{\text {th }}$, 2020]. Availableat: http://www.acumar.gob.ar/ wp-content/uploads / 2016/12/Dosier-EISAAR-Don-JuanLa-Matanza.pdf. 